\title{
All talk, little action: precaution and European chemicals regulation
}

\author{
Noelle Eckley and Henrik Selin
}

\begin{abstract}
The European Union has chosen the precautionary principle as a key guiding principle to achieve more effective policy-making on risks, by moving away from preventive regulation towards more precautionary regulation. Precautionary language has been a part of European Community law for over a decade; however, whether its establishment has had any real effect on European policymaking and regulations is more unclear. This article examines whether the introduction of precautionary language in Community texts has had an effect on the process by which potential risks associated with hazardous chemicals are managed. The article focuses on the two cases of polychlorinated biphenyls (PCBs) and brominated flame retardants (BFRs), and covers the time before, during, and after the Community introduction of the precautionary principle. The article finds that there has been a marked change in the way environmental risks are conceptualized and discussed, but a clear effect in regulatory practice has yet to be seen. Current proposals to revise Community chemicals management, however, contain elements that could enhance precautionary regulation.

KEY WORDS Brominated flame retardants (BFRs); chemicals; chemicals management; European Union; polychlorinated biphenyls (PCBs); precautionary principle.
\end{abstract}

\section{INTRODUCTION}

Policy-makers in multiple areas of regulation are faced with the challenge of making socially acceptable decisions on controversial issues characterized by significant risk and uncertainty. Scientific and technical information is increasingly utilized in policy-making on these kinds of issues, including pharmaceutical drugs, food security, and a wide range of environmental issues. However, scientific and technical information in policy-making can be contentious. Seeking to clarify issues relating to the use of scientific and technical information in Community policy-making, the European Commission in June 2002 published a Communication detailing principles and guidelines for the use of expert advice (European Commission 2001a). The role of experts and use of

Journal of European Public Policy

ISSN 1350-1763 print; 1466-4429 online (C) 2004 Taylor \& Francis Ltd

http://www.tandf.co.uk/journals

DOI: $10.1080 / 1350176042000164316$ 
expert advice in policy-making have also been the subject of extensive academic attention (Weinberg 1972; Jasanoff 1990; Liftin 1994; Jasanoff and Wynne 1998; Clark et al. 2002).

A pitfall that often plagues decision-making on issues characterized by risk and uncertainty is that the existence of uncertainties can lead to a legislative standstill that results in undesirable harm to the environment and human health. In policy-making on environmental issues, there has often been a lengthy process between the first scientific 'early warnings' about potentially serious risks to the environment and human health, and subsequent policy action to address these risks, as a result of uncertainties delaying policy action. Studies show that much environmental and human health damage could have been avoided by a quicker policy response to past early warnings. Policymakers have been more likely to not regulate something that later turned out to be harmful (a so-called 'type 1' error), than to err on the side of caution and regulate something despite uncertainty about risks to the environment and human health (Harremöes et al. 2002).

The prevalence of type 1 errors creates a need to find tools and procedures to avoid uncertainty becoming a roadblock to effective protection of the environment and human well-being. The European Union (EU) and its member states have chosen the precautionary principle as a key guiding principle for policy-making on issues characterized by uncertainty and risks, aiming to limit type 1 errors. ${ }^{1}$ Community treaties and texts state that precaution should apply to all areas of Community policy-making (European Commission 2000b). The precautionary principle is intended to reduce unwanted harm by moving away from preventive regulation towards more precautionary regulation. Applying prevention, regulatory action is taken first when it is believed that something has been clearly demonstrated to be dangerous. In contrast, precaution involves regulating under conditions of uncertainty about risks (Sandin et al. 2002).

The precautionary principle, in one of its most widely cited formulations, states that 'where there are threats of serious or irreversible damage, lack of full scientific certainty shall not be used as a reason for postponing costeffective measures to prevent environmental degradation' (United Nations Conference on Environment and Development 1992). Issues relating to the precautionary principle are addressed in a substantial body of literature, and the principle has both strong advocates and critics (O'Riordan and Cameron 1994; Freestone and Hey 1996; Raffensperger and Tickner 1999; O’Riordan et al. 2001; Harremöes et al. 2002; Sandin et al. 2002). Most of the literature on the precautionary principle is theoretical, normative or prospective: that is, it examines theoretical aspects of the precautionary principle, or addresses how it might be or should be applied (e.g. Tickner 1999; Stirling and Mayer 2000). In contrast, this article empirically examines the effect (if any) that an increasing acceptance of the precautionary principle in theory has had in practice on Community chemicals management.

Community chemicals management is an interesting case study of the 
influence of precaution for a number of reasons. The European Community/ Union has a comparatively long history of inclusion of precautionary language in treaties and texts, stating that precaution should guide all Community policy-making (European Commission 2000b; Jordan 2001). Legislation on hazardous chemicals is a central, long-standing component of Community environmental law that has been identified as generally suitable for precautionary action (O'Riordan and Cameron 1994; Sandin and Hansson 2002). Yet, O'Riordan and Cameron noted in 1994 that the European Community was sympathetic to the precautionary principle in theory, but that its actual influence on Community regulation seemed to be only marginal. Almost a decade has passed since the observation by O'Riordan and Cameron: has Community decision-making on chemicals become more precautionary over the past decade? What is the prospect for the future influence of precautionary thinking on Community chemicals management?

More specifically, this article examines and compares two specific cases of Community chemicals regulations: polychlorinated biphenyls (PCBs) and brominated flame retardants (BFRs). Several factors make such a comparison both possible and relevant. Hazardous chemicals have been regulated over a long period of time, and therefore drawing comparisons between past and present regulatory actions and decision-making processes is relatively straightforward. Further, PCBs and BFRs are two groups of industrial chemicals that exhibit similar characteristics (both are toxic, persistent, and bioaccumulative); have been linked to similar environmental and human health risks (e.g. reproductive, carcinogenic, and tumorigenic effects); have been regulated in some fashion for a decade or longer; and are still subject to active domestic and international assessment and policy-making.

The article traces and compares the history of the development of scientific knowledge and corresponding Community action on PCBs and BFRs, with specific reference to the emergence and development of precautionary thinking. In examining the possible impact of precaution, there are several factors to look for. Specifically, scientific early warnings would be more likely to be heard and emerge on the policy agenda more quickly. As well, policy-makers would be more likely to make quick decisions acting on these warnings: lack of scientific certainty would be less likely to stall issue progress, and the burden of proof for taking decisions would be lower. Data for the study consist of scientific assessments from governmental and intergovernmental organizations, reports from non-governmental and industry organizations, scientific literature, and existing studies of the precautionary principle and chemicals management. These printed sources are supplemented by interviews with assessors, policymakers, and representatives of interest groups involved in Community chemicals management. ${ }^{2}$

In the following section Community chemicals management and the introduction and development of the precautionary principle are discussed. This is followed by a study of Community regulatory measures on PCBs and BFRs, also noting the level of relevant scientific knowledge available at different 
times. Based on this study, the two cases are compared and analysed with regard to the level of precautionary action that has been taken and if that has changed over time. The final two sections summarize the impact of precaution on Community action on PCBs and BFRs, highlights the main explanatory factors, and provides some brief remarks on the future of precaution in Community chemicals management.

\section{COMMUNITY CHEMICALS MANAGEMENT AND THE PRECAUTIONARY PRINCIPLE}

Community environmental policy-making has frequently been driven by northern European member states. Action by Denmark, Germany, and the Netherlands was important in expanding Community environmental policy in the 1980s and early 1990s. Such action was based on their often more stringent domestic legislation than corresponding Community legislation, seeking to raise Community standards to the same levels as their own domestic standards. After the Community enlargement in 1995, Denmark, Germany, and the Netherlands were joined by three more environmental leader states; Austria, Finland, and Sweden. Since 1995, these six countries have sought to initiate stronger Community legislation in multiple environmental areas (Andersen and Liefferink 1997; Liefferink and Andersen 1998; McCormick 2001). In particular, Sweden has prioritized chemicals policy (Kronsell 1997).

Approximately 100,000 chemicals are regularly used for commercial purposes within the European Community (European Commission 2001b). Community policy on hazardous chemicals has tracked the development of Community environmental policy. The first Community Directive on hazardous chemicals, from 1967 (67/548) - like early Community environmental legislation in general - was primarily directed at harmonization of regulations and standards across member states for the purpose of facilitating the development of the common market. In the 1970s, additional Directives developed Community chemicals legislation on protecting direct users and consumers from hazardous substances. From the late 1980s, Community chemicals assessment and legislation has been expanded based on a broader concern of the effects of hazardous chemicals on human health and the environment (McCormick 2001).

Risk assessments using scientific and socio-economic information have historically been an integral part of chemicals management. They have traditionally been used to help analyse whether a specific chemical poses an unreasonable risk that warrants policy responses in the form of partial restrictions or total bans. A central challenge for chemicals risk assessment is to find an effective way to assess whether a certain chemical poses socially unacceptable risks and requires regulations. This involves weighing the risks and benefits of chemical use. There have been numerous studies of risk assessment processes (Jasanoff and Wynne 1998). Many advocates of the precautionary principle have criticized traditional methods of risk assessment, 
particularly those based on 'sound-science' approaches that emphasize scientific certainty, for being too reactive and often resulting in type 1 errors (Raffensperger and Tickner 1999). Some literature has emphasized the subjective nature of risk assessments, stressing the overlaps and mutual influence between science and politics in assessment and policy-making (Bäckstrand 2001; Selin and Eckley 2003).

The precautionary principle is intended by its proponents to lower the evidentiary bar for policy-making on risks, such as the use of human-made chemicals, based on best available risk assessments. In a regulatory system not based on precaution, substantive evidence of serious harm would have to be presented (often by a regulatory agency) before policy actions would be taken. In a precautionary regulatory system, the burden of evidence would be lowered. As such, the precautionary principle is designed to prevent lack of full scientific consensus from being a pitfall for effective policy-making and protection of human well-being. Precautionary thinking also often includes a shifting of responsibility in proving/disproving harm: for example, the manufacturers and/ or sellers of a chemical need to put forward information showing that harm is unlikely before it can be marketed, rather than a regulatory authority having the responsibility to prove that the product is harmful before it can be regulated.

Table 1 presents a timeline of the domestic and international introduction and development of the precautionary principle. The precautionary principle was first introduced in Germany as the Vorsorgeprinzip in the early 1970s (Boehmer-Christiansen 1994). A 1973 Swedish law established an obligation to take precautionary measures on products hazardous to human health and the environment (Sandberg 2001). Germany, Sweden and other northern European environmental leader states continued to develop domestic precautionary approaches in the 1970s and early 1980s, but it was not until the mid-1980s that the precautionary notion began to emerge in international agreements (Saladin 2000). The first multilateral environmental treaty to make specific reference to precaution was the 1985 Vienna Convention on Ozone Depleting Substances, which refers to 'precautionary measures' that should be taken at national and international levels (Cameron 2001).

Shortly after reference to precaution in the Vienna Convention, other international environmental agreements began to include precautionary language. Many of them were regional northern European agreements championed by the regional environmental leader states which had come relatively far in using precautionary language in domestic legislation and regulation. For example, in 1987, the North Sea Ministerial Declaration recommended a 'precautionary approach' for hazardous substances even before clear causeeffect linkages had been scientifically determined. The Nordic Council in 1989 stressed the need for an effective precautionary approach in regulation. Another formulation appeared in the 1990 Bergen Ministerial Declaration on Sustainable Development under the United Nations Economic Commission for Europe (UNECE). One of the most noticed international formulations of 
Table 1 Precautionary principle timeline

\begin{tabular}{|c|c|c|c|}
\hline Year & National formulations & EU formulations & International formulations \\
\hline $\begin{array}{l}\text { early } \\
1970 \text { s }\end{array}$ & $\begin{array}{l}\text { The German } \\
\text { Vorsorgeprinzip first } \\
\text { presents the notion of } \\
\text { precautionary thinking }\end{array}$ & & \\
\hline 1973 & $\begin{array}{l}\text { Swedish obligation to } \\
\text { take precautionary } \\
\text { measures in act on } \\
\text { products hazardous to } \\
\text { human health and } \\
\text { environment }\end{array}$ & & \\
\hline 1985 & & & $\begin{array}{l}\text { Vienna Convention on } \\
\text { Ozone Depleting } \\
\text { Substances refers to } \\
\text { 'precautionary measures' }\end{array}$ \\
\hline 1987 & & & $\begin{array}{l}\text { North Sea Ministerial } \\
\text { Declaration recommends } \\
\text { a 'precautionary } \\
\text { approach' for most } \\
\text { dangerous substances } \\
\text { even before a causal link } \\
\text { has been established by } \\
\text { clear scientific evidence }\end{array}$ \\
\hline 1989 & & & $\begin{array}{l}\text { Nordic Council: need for } \\
\text { an effective precautionary } \\
\text { approach }\end{array}$ \\
\hline 1990 & & $\begin{array}{l}\text { Dublin Declaration } \\
\text { refers to principle of } \\
\text { precautionary action } \\
\text { when developing } \\
\text { Community policy }\end{array}$ & \\
\hline 1992 & & & $\begin{array}{l}\text { Rio Declaration formulates } \\
\text { Principle } 15 \text { on precaution }\end{array}$ \\
\hline 1993 & & $\begin{array}{l}\text { Maastricht Treaty: } \\
\text { Community policy on } \\
\text { the environment shall } \\
\text { be based on the } \\
\text { precautionary principle }\end{array}$ & \\
\hline 2000 & & $\begin{array}{l}\text { EU Communication on } \\
\text { the precautionary } \\
\text { principle }\end{array}$ & \\
\hline
\end{tabular}


the principle came in Principle 15 of the 1992 Rio Declaration (as cited above), and precautionary language is a staple in most post-1992 international environmental agreements.

The environmental leader states have been among the most vocal supporters of the precautionary principle within the European Community (Jordan 2001). Again, such action has stemmed from a desire to have their early domestic acceptance of precautionary thinking in addressing environmental and human health risks, particularly in the cases of Germany and Sweden, accepted and incorporated at the Community level. Early resistance against the precautionary principle came from other Community members, such as the United Kingdom. The sudden and unexpected change of the British government in support of the precautionary principle in 1988 facilitated its introduction into Community texts (Haigh 1994). The Community has also sought to 'export' the precautionary principle by advocating its application in several international environment and trade arenas since the early 1990s (ENB 2000; European Commission 2000a).

The 1990 Dublin Declaration contained the first joint political statement that Community policy would be developed based on a principle of precautionary action. The first legally binding Community formulation of the principle came with the 1992 Maastricht Treaty, in which it is stated that all Community policy on the environment shall be based on the precautionary principle. After the Maastricht Treaty, the principle has continued to be included in numerous EU texts and court decisions. Yet, formulations of the precautionary principle have been criticized for being vague (Sandin 1999; Sandin et al. 2002), and member states have differed in their interpretation and application of the precautionary principle. In addition, Directorates within the European Commission have exhibited different attitudes toward the precautionary principle, and the development of the 2000 Community Communication on precaution was the result of lengthy interdepartmental battles (European Commission 2000b; Jordan 2001). ${ }^{3}$

Research has attempted to characterize conditions under which the precautionary principle is likely to have the largest influence on regulation (Stirling 1999). O'Riordan and Cameron (1994) predicted four such conditions: where new technologies are proposed in well-regulated policy areas where the public is generally risk-averse; where tools such as risk assessments or life-cycle analysis are used for assessing what risks are deemed socially tolerable; where there is an existing culture of protection of vulnerable populations; and in transparent and open policy-making systems. Community chemicals management fits well all these conditions: it is a long-standing, well-regulated area in a context of a democratic policy-making system for environmental and human health protection; European public opinion is often risk-averse towards chemicals; and risk assessment and life-cycle analysis are commonly employed in chemicals regulation.

However, just because the northern European environmental leader states have been successful in promoting the inclusion of precautionary language 
in Community texts, and chemicals management is generally suitable for precautionary approaches, there is no guarantee that precautionary thinking will have a direct effect on Community policy-making on specific issues, as was noted by O'Riordan and Cameron (1994) a decade ago. Has there been an increasing influence of precautionary thinking on the Community policymaking on specific hazardous chemicals such as PCBs and BFRs over time, or is it, in fact, a case of all talk and no action? Further, Community chemicals management is currently under major revision, and environmental leader states have been strong advocates of increasing precaution in regulation (Swedish Government 2002); are there any indications that ongoing changes can make Community chemicals management more precautionary?

\section{REGULATING POLYCHLORINATED BIPHENYLS AND BROMINATED FLAME RETARDANTS}

This section briefly reviews the case history of regulations on PCBs and BFRs, paying particular attention to the level of scientific knowledge and the corresponding policy actions taken by environmental leader states and the European Community. Tables 2 and 3 present a timeline of the development of scientific knowledge and actions taken on PCBs and BFRs, respectively.

\section{Polychlorinated biphenyls}

PCBs are mixtures of chlorinated hydrocarbons that were first synthesized in 1881. They began to be commercially produced and marketed by Monsanto in 1929. Production and use of PCBs increased rapidly after World War II, and PCBs were widespread in a variety of products world-wide by the 1970s (Koppe and Keys 2002). Because of their insulating capacity and effectiveness as flame-retardants, PCBs were widely used in transformers and other electrical equipment. Additional PCB uses included hydraulic and lubricating oils, paints, lacquers and varnishes, and as pigments in various plastics (Ritter et al. 1995).

The first scientific warning relating to PCB-like substances came as early as 1899 when the skin disease chloracne was linked to direct, high exposure of workers to chlorinated organic chemicals. Further warnings on the health effects in workers exposed to PCBs were made in the early 1930s (Koppe and Keys 2002). These concerns were addressed through the use of better protective clothing for direct handlers, and drew only minor scientific and public attention. More extensive scientific and policy attention to PCBs was not paid until the 1960s as part of a growing concern with hazardous chemicals writ large (Carson 1962).

The first public scientific warning that PCBs were widespread in the environment came in 1966 when Sören Jensen was reported to have detected PCBs in white-tailed eagles in Sweden. Historical analysis by Jensen dated such environmental traces back to 1944. Jensen also found evidence of PCBs 
86 Journal of European Public Policy

Table 2 PCBs timeline

\begin{tabular}{|c|c|c|}
\hline Year & Scientific knowledge & Actions taken \\
\hline 1881 & PCBs first synthesized & \\
\hline 1889 & Skin condition chloracne identified & \\
\hline 1929 & & $\begin{array}{l}\text { Large-scale commercial PCB } \\
\text { production and use begins }\end{array}$ \\
\hline 1930s & $\begin{array}{l}\text { Monsanto becomes aware of PCB } \\
\text { health effects }\end{array}$ & \\
\hline 1966 & $\begin{array}{l}\text { First public scientific warning of } \\
\text { widespread existence of PCBs in } \\
\text { environment and humans }\end{array}$ & \\
\hline 1968 & $\begin{array}{l}\text { Yusho rice oil poisoning incident, } \\
\text { Japan }\end{array}$ & \\
\hline 1972 & & $\begin{array}{l}\text { First government action: Germany } \\
\text { bans open uses of PCBs; Monsanto } \\
\text { begins to restrict sales of PCBs } \\
\text { voluntarily }\end{array}$ \\
\hline 1973 & & $\begin{array}{l}\text { First international action: OECD } \\
\text { recommends bans on new open uses } \\
\text { of PCBs }\end{array}$ \\
\hline 1974 & & $\begin{array}{l}\text { First international legally binding } \\
\text { action: the Helsinki Convention } \\
\text { assigns parties with a responsibility to } \\
\text { 'counteract' the introduction of PCBs } \\
\text { into the Baltic Sea }\end{array}$ \\
\hline 1976 & & $\begin{array}{l}\text { Community Directive } 76 / 403 \\
\text { regulates disposal of PCBs; } \\
\text { Community Directive } 76 / 769 \text { bans } \\
\text { 'open' uses of PCB mixtures }>0.1 \\
\text { per cent }\end{array}$ \\
\hline 1978 & & $\begin{array}{l}\text { Production of PCBs ends in United } \\
\text { Kingdom; Sweden and Germany ban } \\
\text { PCB use in closed systems }\end{array}$ \\
\hline 1979 & Yucheng poisoning accident, Taiwan & $\begin{array}{l}\text { Production of PCBs ends in United } \\
\text { States }\end{array}$ \\
\hline $\begin{array}{l}\text { early } \\
1980 \text { s }\end{array}$ & $\begin{array}{l}\text { Evidence that PCBs are widespread } \\
\text { environmental contaminants grows; } \\
\text { evidence of harm from } \\
\text { bioaccumulation mounts }\end{array}$ & \\
\hline
\end{tabular}


Table 2 Continued

\begin{tabular}{|c|c|c|}
\hline Year & Scientific knowledge & Actions taken \\
\hline 1985 & & $\begin{array}{l}\text { Community Directive } 85 / 467 \text { prohibits } \\
\text { use of PCB mixtures }>0.01 \text { per cent } \\
\text { in certain closed systems; a HELCOM } \\
\text { recommendation phases out } \\
\text { production and use of PCBs }\end{array}$ \\
\hline 1987 & & $\begin{array}{l}\text { OECD further action on PCBs: } \\
\text { recommends that countries stop } \\
\text { manufacture, import, export, sale by } \\
\text { 1989; recommends accelerating } \\
\text { phase-out of PCBs in use }\end{array}$ \\
\hline 1989 & & $\begin{array}{l}\text { Community Directive } 89 / 667 \text { prohibits } \\
\text { use and reuse of PCB mixtures } \\
>0.005 \text { per cent }\end{array}$ \\
\hline 1990 & & $\begin{array}{l}\text { Third North Sea Conference agrees to } \\
\text { phase out use of PCBs by } 1999\end{array}$ \\
\hline $\begin{array}{l}\text { early- } \\
\text { mid } \\
1990 \text { s }\end{array}$ & $\begin{array}{l}\text { Developmental effects identified. } \\
\text { Growing evidence of endocrine } \\
\text { disruption }\end{array}$ & \\
\hline 1995 & & $\begin{array}{l}\text { UNEP Decision } 18 / 32 \text { includes PCBs } \\
\text { on a list of persistent organic } \\
\text { pollutants (POPs) subject to global } \\
\text { negotiations }\end{array}$ \\
\hline 1996 & $\begin{array}{l}\text { Jacobson and Jacobson study on } \\
\text { developmental effects from PCB- } \\
\text { contaminated fish; Our Stolen } \\
\text { Future published }\end{array}$ & $\begin{array}{l}\text { Community Directive } 96 / 59 \text { requires } \\
\text { disposal of identified PCBs by } 2010\end{array}$ \\
\hline 1998 & & CLRTAP protocol on POPs adopted \\
\hline 2001 & & $\begin{array}{l}\text { Stockholm convention on POPs } \\
\text { adopted }\end{array}$ \\
\hline
\end{tabular}

in his own, his wife's and his five-month-old daughter's hair (Anonymous 1966; Jensen et al. 1969). In 1968, the Yusho rice oil poisoning incident in Japan - in which a PCB leak from a factory contaminated rice oil, causing many people to become ill - drew increased attention to the adverse human health impacts of PCBs (Nichols and Crawford 1983).

Germany was the first country to take regulatory action on PCBs based on the scientific information on environmental dispersal from the late 1960s, banning 'open uses' (that is, uses which resulted in direct releases to the environment) in 1972 (Helsinki Commission 2001b). Sweden quickly followed 
suit and also banned open uses of PCBs in 1973 (Helsinki Commission 2001b). These first national regulatory actions were thus taken only a few years after the first public warning of widespread contamination of PCBs in the environment. Around the same time, Monsanto began to restrict sales of PCBs voluntarily, allowing sales of PCBs only to be used in closed systems (Canadian Council of Resource and Environment Ministers 1986).

The first international policy decision identifying PCBs as a hazardous chemical was the 1973 Decision of the Council of the Organization for Economic Co-operation and Development (OECD) that member states should restrict the production and use of PCBs (OECD 1973a; Lönngren 1992). ${ }^{4}$ Advocating a limited precautionary approach that was uncommon in an international forum at that time, an OECD report on $\mathrm{PCB}$ s from the same year stated:

Although the toxicity of PCBs is not well known, and despite the fact that the quantities of PCBs dispersed in the environment do not represent an immediate hazard to man's health, the persistent nature of these compounds, and the risk of accumulation in the environment, has justified that certain control measures be taken in advance of full knowledge of the real risks of PCBs and their pathways into the environment.

(OECD 1973b)

In 1974, the Convention on the Protection of the Marine Environment of the Baltic Sea Area - to which several northern European environmental leader states were active parties - assigned member states a responsibility to 'counteract' the airborne and waterborne introduction of PCBs into the Baltic Sea. ${ }^{5}$ The European Community took its first action on PCBs in 1976, banning the use of PCBs in open applications (Directive 76/769). In 1978, production of PCBs was halted in the United Kingdom. Also in 1978, both Sweden and Germany extended their domestic bans beyond the international regulations to include 'closed uses' of PCB (that is, uses in closed systems with no direct environmental emissions), again acting as environmental leader states ahead of Community legislation (Helsinki Commission 2001a).

Scientific environmental assessments in the early 1980s demonstrated that environmental releases of PCBs continued to be a major international problem despite the early PCB controls among primarily northern industrialized countries (Moilanen et al. 1982; Olsson and Reutergårdh 1986; Larsson and Okla 1989). There were two major reasons for this. First, allegedly closed uses of PCBs were in fact emitting PCBs to the environment for widespread dispersal. Second, production and use of PCBs continued outside Europe and North America, and these releases caused global pollution problems through long-range transport. Evidence that PCBs caused harm to wildlife through their bioaccumulation was also increasing, indicating that serious effects could be expected to occur even at very low levels of exposure, although some uncertainty remained.

In response to the new scientific data, domestic and international PCB 
regulations were strengthened in several cases in the 1980s, in part based on precautionary thinking. A 1981 OECD document states that in new legislation for chemicals, 'The primary objective has become prevention rather than cure with respect to the entry of hazardous chemicals into the environment' (OECD 1981). In 1985, an amendment to Directive $76 / 769$ on the marketing and use of dangerous substances prohibited the use of PCBs in certain closed systems from July 1986 (Directive 85/467). That same year, the Helsinki Commission (HELCOM) of the 1974 Helsinki Convention adopted Recommendation 6/1, requiring member states to stop PCB production and marketing of goods containing PCBs from 1987, and set up national programmes to identify and dispose of PCB-containing articles (Selin and VanDeveer 2004).

In 1987, the OECD, based on mounting scientific evidence of impacts as well as new toxicity concerns emerging in the scientific literature, recommended that all its members prohibit the import, export, manufacture, and sale of PCBs by 1989, and recommended accelerating the phase-out of PCBs in use (OECD 1987). One year later, the European Community also took trade action, and Regulation 1734/88 set up a common notification system for trade in twenty-one chemicals, including PCBs. A 1989 Directive (89/677) prohibited the use and reuse of $\mathrm{PCBs}$ and any mixture containing them in more than 0.005 per cent by weight. In 1990, the Third North Sea Conference agreed to phase out uses of PCBs by 1999 .

In the 1990s, concern grew about the effects of PCBs on humans through environmental exposure. Previously, understanding of human risks of environmental exposure had been limited, but scientific advancements in the late 1980s and early 1990s indicated increased concern. The new human data together with accumulating environmental data confirming earlier findings stimulated several political developments. In 1991, a comprehensive assessment on a set of so-called persistent organic pollutants (POPs) that included PCBs began under the UNECE and the Convention on Long-Range Transboundary Air Pollution (CLRTAP), pushed by Canada and the European environmental leader states, especially Sweden (Eckley 2002; Selin 2003; Selin and Eckley 2003). In 1995, the Governing Council of the United Nations Environment Programme selected PCBs and eleven other chemicals for global action (UNEP 1995).

In 1996, the much publicized book Our Stolen Future presented the 'endocrine disruptor hypothesis'. The hypothesis was based on data from wildlife and humans and suggested that synthetic chemicals such as PCBs were acting like the hormone oestrogen, causing reproductive and behavioural abnormalities (Colborn et al. 1996; Krimsky 2000). Another much noticed study from 1996 linked consumption of PCB-contaminated fish by mothers in the Great Lakes area with impaired cognitive functioning in their children (Jacobson and Jacobson 1996). In part reacting to the new PCB data, the European Community in 1996 adopted Directive 96/59 (replacing Directive 76/403), setting guidelines for disposal and decontamination of PCB wastes and $\mathrm{PCB}$-containing equipment, and requiring member states to decontamin- 
ate or dispose of equipment containing 500 parts per million (ppm) or greater PCBs by 2010. Activities on PCBs were also expanded under HELCOM and the Oslo-Paris (OSPAR) Commission, two progressive fora on hazardous chemicals management dominated by northern European environmental leader states and to which the European Community is a contracting party (Skjærseth 2000; Selin and VanDeveer 2004). ${ }^{6}$

In 1998, a CLRTAP POPs protocol was concluded. In 2001, the global Stockholm POPs convention was adopted. The European Commission and all the Community environmental leader states participated actively in the negotiations of both these POPs agreements that contain stringent PCB regulations (Eckley 2002; Selin 2003; Selin and Eckley 2003). ${ }^{7}$ Under the CLRTAP POPs protocol, no production of PCBs is allowed except for countries with economies in transition, which shall eliminate production no later than 2005. Parties are committed to the elimination of the use and destruction or decontamination of identifiable PCBs in equipment containing PCBs no later than 2010, or 2015 for countries with economies in transition (UNECE 1998). Under the Stockholm POPs convention, all production of PCBs is banned. PCBs used in equipment shall be eliminated by 2025 (UNEP 2001). Neither of the two POPs agreements, however, goes beyond what the EU had already decided on PCBs by 1996.

\section{Brominated flame retardants}

Many BFRs have properties quite similar to PCBs. Polybrominated biphenyls (PBBs) and polybrominated diphenyl ethers (PBDEs) are the two BFRs that have attracted greatest concern to date in regulatory arenas. ${ }^{8}$ PBBs are similar in structure to PCBs, except that where PCBs have chlorine atoms, PBBs have bromine atoms. PBDEs have a slightly different chemical structure in which the two benzene rings are separated by an oxygen atom. BFRs are used extensively in electronic products such as computers and TV sets to prevent fires (Danish Environmental Protection Agency 2000).

The toxicity of PBBs was revealed in 1973, after an accident in Michigan, USA, in which farm animals were exposed to $\mathrm{PBB}$ and fell acutely ill; people were then exposed to PBB through meat consumption (KEMI 2000). In 1978, the immunotoxic potential of PBBs was identified in humans, in a follow-up study to the Michigan accident (Bekesi et al. 1978). A 1979 hazard assessment of PBBs done by the US Environmental Protection Agency showed that they were teratogenic, embryotoxic, and immunosuppressive in mice and rats, and carcinogenic in rats (OECD 1994). Suspicions about their toxicity and ability to bioaccumulate led industry in the US to voluntarily discontinue production and use of the substances in the 1970s (OECD 1994).

PBDEs were first detected in the environment in 1981 (Andersson and Blomkvist 1981). The first levels in the environment not subject to accidental release of PBBs were reported in 1987 (Jansson and Asplund 1987). In the 
report, the authors noted that the presence of these compounds in samples from remote areas indicated world-wide distribution of the compounds.

The presence of $\mathrm{PBB}$ in products that can make direct skin contact has been subject to Community regulation since 1983 when Directive 83/264 identified PBBs as harmful to health. Germany was the first country to act on heightened concerns about BFRs in the general environment, and proposed in the late 1980s a Community-wide ban on PBDEs and PBBs. This proposal was rejected because it was deemed infeasible; however, Germany acted to limit domestic production of PBDEs and PBBs through its laws on dioxin (dioxin is a by-product of PBDE and PBB production) (KEMI 1999). German industry voluntarily discontinued use of PBBs and PBDEs in 1986 (KEMI 1999). Again, Sweden joined Germany as a leading state: in 1990, a Swedish government bill established that use of BFRs should be limited, and the most dangerous should be phased out (KEMI 1999).

In 1991, the European Commission issued a proposal for a directive on PBDEs, which would have limited PBDE use in articles to 0.1 per cent (Hardy 1997). At this point, there was little scientific information about the toxicity of PBDEs in humans, but it was clear that they were widespread environmental contaminants, and that they were accumulating. The proposed PBDE directive was withdrawn in 1994, noting uncertainty in the scientific community about PBDE dangers to human health and the environment, and no concrete Community action was taken to address the growing suspicion that BFRs might pose a risk to human health and the environment. This occurred at the same time as there was an increasing reference to the precautionary principle in Community texts, including the 1992 Mastricht Treaty stating that all Community environmental policy should be based on the precautionary principle.

Despite mounting concern by several environmental leader states and organizations about PBDEs, the use of these substances doubled during the period 1984-92, from 20,000 tonnes to 40,000 tonnes (Tegethoff 2000). In 1994, the International Programme on Chemical Safety (IPCS) published environmental health risk documents on PBBs and PBDEs (IPCS 1994a, 1994b), and the OECD published a risk-reduction monograph on PBBs and PBDEs (OECD 1994). These reports indicated that there was little evidence to indicate human effects of PBDEs at exposure levels. However, given the available evidence on persistence and bioaccumulation, the OECD recommended that penta-BDE and tetra-BDE as well as PBBs should not be used. At the same time, evidence of immunologic and endocrine effects of PBDEs began to be published.

The first international action on BFRs based on their environmental risks was taken by the OECD in 1995 (all earlier action on BFRs had been generated by concern for human health). This was eight years after a scientific report had raised warnings that these compounds could be world-wide pollutants (Jansson and Asplund 1987), and three years after the precautionary principle was included in the Rio Declaration. The OECD action consisted 
of a voluntary agreement with industry to limit production of PBBs. Industry pledged to discontinue all production of PBBs except for deca-BB. Production of PBDEs was allowed within guidelines for pollution prevention.

A comparison of the OECD decisions with the state of the science as communicated at the same time by the IPCS gives some insight into the level of proof that decision-makers used. For PBBs, the IPCS identified high persistence and bioaccumulation and potential adverse effects at very low levels after long-term exposure. For deca-BB (which was exempted from this agreement), the report noted limited toxicity data, extreme persistence and potential breakdown in the environment, and more toxic persistent compounds formed through combustion. These characteristics were also noted for octa$\mathrm{BB}$, which was subject to the phase-out. For penta-BDE, the IPCS noted persistence in the environment and bioaccumulation in living organisms; however, reproduction, long-term toxicity, and carcinogenicity studies were not available. For tetra-BDE, persistence and bioaccumulation data were available, but not data on toxicity. For other PBDEs, the IPCS concluded that data were not sufficient to recommend action.

A Swedish report in 1996 analysing risks to human health and the environment from BFRs concluded that available information on environmental and health properties and exposure was inadequate; however, given existing knowledge concerning concentrations in the environment, bioaccumulation and persistence, it recommended that the use of PBDEs and PBBs must cease (KEMI 1999). With information similar to that available to the IPCS, Sweden recommended ceasing production of all the compounds. In July 1998, BFRs as a group were included on a list of chemicals identified for priority action in the Sintra agreement of the OSPAR, very actively pushed by Sweden and other regional environmental leader states. The aim is to cease the emissions of hazardous substances into the marine environment of the Northeast Atlantic, and return concentrations to 'close to zero' (OSPAR 1998a, 1998b).

BFRs became a more high-profile issue in 1998, following an international scientific conference in Stockholm: 'Halogenated Environmental Organic Pollutants', also known as Dioxin '98 (ENDS 1998a). This conference was part of a series of annual conferences that began with a meeting in Rome in 1980 (Hutzinger et al. 1982). Though the focus of the conferences has broadened since 1980 to encompass not only dioxin but a whole range of additional organic pollutants, the name 'dioxin' continues to be used. At the Dioxin '98 conference, BFRs were a special focus and research was presented which indicated an increase in the level of BFRs in the breast milk of Swedish women.

At the time of the Dioxin '98 conference, the level of knowledge about PBDEs and PBBs was significantly greater than in 1994-96. In addition to the increasing knowledge about human health exposure and effects, such as that presented at the conference, additional measurements of BFRs in the environment had also been identified. In 1998, an article in Nature identified 
Table 3 BFRs timeline

\begin{tabular}{|c|c|c|}
\hline Year & Scientific knowledge & Actions taken \\
\hline 1970s & $\begin{array}{l}\text { PBBs: suspicion of toxicity and ability } \\
\text { to bioaccumulate }\end{array}$ & $\begin{array}{l}\text { US industry voluntarily discontinues } \\
\text { production and use of PBBs }\end{array}$ \\
\hline 1978 & $\begin{array}{l}\text { Immunotoxic potential of PBBs in } \\
\text { humans identified }\end{array}$ & \\
\hline 1979 & $\begin{array}{l}\text { US EPA hazard assessment of PBBs } \\
\text { shows they are teratogenic, embryo- } \\
\text { toxic, and immunosuppressive in mice } \\
\text { and rats, and carcinogenic in rats }\end{array}$ & \\
\hline 1981 & $\begin{array}{l}\text { PBDEs first detected in the } \\
\text { environment }\end{array}$ & \\
\hline 1984 & & Use of PBDEs: $20,000 \mathrm{t}$ \\
\hline 1987 & PBBs first detected in the environment & \\
\hline $\begin{array}{l}\text { late } \\
1980 s\end{array}$ & & $\begin{array}{l}\text { Germany proposes Community-wide } \\
\text { ban on PBDEs and PBBs }\end{array}$ \\
\hline 1990 & $\begin{array}{l}\text { Netherlands conducts risk } \\
\text { assessment of PBBs, PBDEs }\end{array}$ & $\begin{array}{l}\text { Swedish government decides most } \\
\text { harmful BFRs should be phased out }\end{array}$ \\
\hline 1991 & & $\begin{array}{l}\text { EU Commission proposal for } \\
\text { directive on PBDEs issued }\end{array}$ \\
\hline 1992 & & Use of PBDEs $40,000 t$ \\
\hline 1994 & $\begin{array}{l}\text { IPCS publishes environmental health } \\
\text { risk document on PBBs, PBDEs; OECD } \\
\text { publishes risk reduction monograph } \\
\text { on selected BFRs (including PBDEs, } \\
\text { PBBs), finds little evidence of human } \\
\text { effects of PBDEs at exposure levels, } \\
\text { but recommends that most should not } \\
\text { be used due to persistence/ } \\
\text { bioaccumulation; evidence of } \\
\text { immunologic and endocrine effects } \\
\text { published }\end{array}$ & \\
\hline 1995 & & $\begin{array}{l}\text { OECD voluntary agreement with } \\
\text { industry to limit production of PBDE } \\
\text { and PBB. } \\
\text { BFRs included in Esbjerg declaration } \\
\text { at } 4 \text { th North Sea Conference (phase- } \\
\text { out). } \\
\text { Proposal for directive on PBDEs } \\
\text { withdrawn; EU risk assessment } \\
\text { process begins }\end{array}$ \\
\hline
\end{tabular}


Table 3 Continued

\begin{tabular}{|c|c|c|}
\hline Year & Scientific knowledge & Actions taken \\
\hline 1998 & $\begin{array}{l}\text { Dioxin ' } 98 \text { conference has a special } \\
\text { focus on BFRs. Evidence of } 50 x \\
\text { increase in concentrations in breast } \\
\text { milk in } 25 \text { years. PBDEs cause brain } \\
\text { damage in young mice }\end{array}$ & $\begin{array}{l}\text { BFRs included in Sintra agreement } \\
\text { of OSPAR convention; HBB included } \\
\text { on HELCOM list of initial priority } \\
\text { substances; HBB included in the } \\
\text { CLRTAP POPs protocol }\end{array}$ \\
\hline 1999 & & $\begin{array}{l}\text { Sweden becomes first country to } \\
\text { introduce a national ban on PBDE } \\
\text { and PBB sale and use; Sweden } \\
\text { proposes Community phase-out of } \\
\text { PBB, PBDE }\end{array}$ \\
\hline 2000 & $\begin{array}{l}\text { EU risk assessment for penta-BDE } \\
\text { published }\end{array}$ & $\begin{array}{l}\text { Denmark publishes 'action plan' on } \\
\text { BFRs. } \\
\text { Production of PBBs ceases }\end{array}$ \\
\hline 2001 & & $\begin{array}{l}\text { Penta-BDE targeted for Community } \\
\text { phase-out }\end{array}$ \\
\hline 2002 & $\begin{array}{l}\text { EU risk assessment for octa-BDE } \\
\text { published }\end{array}$ & $\begin{array}{l}\text { Directive } 2002 / 95 \text { on hazardous } \\
\text { substances in manufactured } \\
\text { equipment requires phase-out of } \\
\text { PBDE, PBB by July 2006; exempts } \\
\text { deca-BDE }\end{array}$ \\
\hline 2003 & & $\begin{array}{l}\text { Directive } 2003 / 11 \text { prohibits } \\
\text { marketing and use of penta-BDE and } \\
\text { octa-BDE }\end{array}$ \\
\hline
\end{tabular}

PBBs and PBDEs in sperm whales stranded on the Dutch coast; these results indicated that these compounds had reached the deep ocean (de Boer et al. 1998). Following the Dioxin '98 conference, both Sweden and Denmark initiated processes of domestic action against the substances, and began to lobby for Community action on their use.

The precautionary principle was highly prominent in policy discussions following the Dioxin '98 conference. Sweden and Denmark explicitly argued for a Community chemicals policy based to a greater extent on precaution. Parallels were drawn in the case of PCBs. In September 1998, Swedish environment minister Anna Lindh was quoted as saying, 'The use of [brominated fire retardants] may well lead to the same disastrous consequences as did the use of the now banned PCBs' (ENDS 1998b). In March 1999, Sweden became the first country to propose a national ban on PBDE and PBB sale and use (ENDS 1999). Sweden also sought a Community-wide phase-out of $\mathrm{PBB}$ and $\mathrm{PBDE}$.

In 2000, the Community risk assessment for penta-BDE was published, 
stating that more data were necessary, and making no explicit recommendations for phase-out. In contrast, the Danish Environmental Protection Agency stated, 'Despite the fact that complete knowledge of the environmental and health effects of PBB and PBDE is not presently available, it seems well-founded to apply the precautionary principle given that the substances have been found in man and the environment and are known to be persistent' (Danish Environmental Protection Agency 2000). In addition, the World Wide Fund for Nature argued that governments and industry should accept the need for precaution: there are so many pollutants now found in wildlife and humans, including breast milk, that urgent measures should be put in place to reduce exposure and releases of substances such as PBDEs' (World Wide Fund for Nature 2000).

Both scientific knowledge and policy action on BFRs continue to evolve. A recent article identified exponential increases in concentrations of PBDEs in Canadian Arctic seals from 1981 to 2000; this is the first time bioaccumulation of these materials has been identified in the Arctic (Ikonomou et al. 2002). A 2001 proposal by the European Commission targeted the phase-out of pentaBDE, mentioning specifically concern about concentrations in breast milk (ENDS 2001). The European Parliament proposed adding octa- and decaPBDEs to the proposed ban (ENS 2001); the final Directive (2003/11) prohibits the marketing and use of penta-BDE and octa-BDE, but excludes deca-PBDEs pending further assessment. Community legislation in late 2002 on hazardous substances in manufactured equipment stipulates that manufacturers are required to cease using PBDE and $\mathrm{PBB}$ in products marketed from 1 July 2006 (Directive 2002/95); this Directive also exempts deca-BDE from regulation. In the meantime, existing restrictions by member states will remain in place. However, these Directives do not regulate some seventy other BFRs that remain in use.

\section{EXAMINING THE TWO CASES: PRECAUTION OR NO PRECAUTION?}

In the PCB and BFR cases, a similar general regulatory pattern is visible. Early indications of adverse effects resulted in domestic regulatory action in a few northern environmental leader states that were among the first to incorporate precautionary thinking in domestic environmental legislation and regulation (e.g. Germany and Sweden). These states were also early in advocating the need for international action on hazardous chemicals. In the case of PCBs, the 1973 OECD decision banned 'open' uses and the 1974 Convention on the Protection of the Marine Environment of the Baltic Sea Area demanded that parties should 'counteract' the airborne and waterborne introduction of PCBs into the Baltic Sea. In the case of BFRs, early international action predominantly consisted of voluntary phase-outs. Community action on PCBs was fairly early in an international context - the first Directive on PCBs, in 1976, banned the use of PCBs in open applications. For BFRs, a Community 
proposal was issued in 1991, but this proposal was later withdrawn on the basis of scientific uncertainty.

Scientific assessments on PCBs in the 1980s showed continuous adverse effects despite early domestic and international policy actions, and contributed to a deeper understanding of their environmental behaviour. This led to further strengthening of domestic regulations in several leader countries which also successfully pressed for additional Community regulations on PCBs throughout the late 1980s and 1990s. In the 1980s, the leader states became more vocal on the need for BFR regulations, based on accumulating scientific knowledge, and again initiated domestic actions ahead of Community policy despite uncertainty about the environmental and human health effects of BFRs. In both the PCB and BFR cases, leader states made increasing references to the need for precautionary action from the late 1980s onwards. In the case of PCBs, the emergence of scientific knowledge of endocrine disruption in the early 1990s drew attention to the problems posed by PCBs still in use. Research presented at the Dioxin '98 conference catalysed a renewed interest in BFRs at the European level based on concern with their suspected endocrine disruption functions in animals and humans.

Looking at the two cases in more detail, the initial policy proposals and actions by the leader states on BFRs seem to be more precautionary than their initial actions on PCBs. The first policy actions on PCBs targeted only 'open uses' while the more complicated 'closed uses' were left unregulated. In contrast, the leading states directly advocated total bans on production or use of substances on BFRs in the late 1980s and early 1990s. Arguments in favour of such action often relied strongly on the precautionary thinking. However, these proposals were generally not accepted outside of the leading states, showing that the leading states' interpretation of precaution in this case was not shared by most other states.

Still, leader states and environmental advocacy groups have been increasingly likely to argue for action based on precaution over the past decade. For example, the idea that bioaccumulation and persistence should be enough evidence to regulate a substance even in the absence of toxicity data based on precaution emerged from those leader states that most strongly support the precautionary principle. Sweden, in particular, has been a leading champion of this approach (Swedish Committee on New Guidelines on Chemicals Policy 2000). This idea, along with a proposal for shifting the burden of proof from regulators to chemical producers, has been pushed by environmental leader states in current discussions of a new chemicals policy (European Commission 2001b; Swedish Government 2002).

It is clear that Community debate on hazardous chemicals over the past decade would have been significantly different in the absence of the precautionary principle. Without the idea of precaution accepted by the Community in its treaties and texts, the leader countries would have been limited to arguing for the ban of PBB and PBDE mainly based on available scientific evidence of risk. However, it is much less clear that the Community regulatory case 
histories of $\mathrm{PCBs}$ and BFRs would have developed differently in the absence of the precautionary principle. One difference between the PCB and BFR cases that seems to have had important implications for Community regulation relates to availability of data on human health risks. For PCBs, knowledge about adverse human health effects (e.g. acute effects from poisoning accidents) emerged at about the same time as knowledge about widespread environmental dispersal and accumulation. Environmental and human health data thereby largely supported each other, which facilitated the introduction of policy regulations on PCBs.

For BFRs, human toxicity data are more unevenly available and this seems to be influential when comparing policy action on PBBs and PBDEs. For PBBs, knowledge about their human toxicity was already available in the late 1970s, and although these substances have not yet been explicitly banned in Europe, their production has been de facto phased out. For PBDEs, a lack of human toxicity information on most congeners has resulted in much slower policy action. The notable exception is penta-BDE, and penta-BDE was also the first congener proposed for bans across Europe. This suggests that despite proposals from leader states that persistent and bioaccumulative substances should be phased out regardless of proven toxicity, Community chemicals regulation still tends to track with the availability of information on human toxicity. In other words, it is to a large extent the explicit availability of specific data on human toxicity that continues to be necessary for Community regulation. This is a preventive rather than precautionary approach to regulation.

There seems to be convincing support for the observation made by a representative of a European industry organization that the Community chemicals debate has shifted from an emphasis on actual risk to potential risk, crediting public perception of previous errors and the public's increasing scepticism of scientific 'facts' as important reasons for this (personal interview 2000). However, while the discourse has changed, actual regulatory decisions taken by European policy-makers do not seem to be based on a significantly lower level of proof. The most recent Community regulation of octa-BDE, and proposals to regulate deca-BDE, without extensive human toxicity information, may be a signal of a more precautionary regulation to come. A representative of a non-governmental organization (NGO) active on European chemicals management drew a parallel between the pervasiveness of the precautionary principle and the increasing acceptance of sustainable development as a concept - both terms have rhetorical value, but are interpreted very differently and face difficulties in implementation on specific issues (personal interview 2001).

Policy-makers and stakeholders from different areas portray a similar picture regarding lack of precaution in actual decision-making. A senior European regulator argued that 'we have learned the lesson, but we have not yet drawn the conclusion in terms of operationalizing' (personal interview 2001). A senior European policy-maker noted that the existence of the precautionary 
principle has not yet changed how scientific information is used in any fundamental way (personal interview 2001). In late 2000, European environmental and consumer NGOs argued in a background paper for a conference on the future of European chemicals policy that the precautionary principle 'has so far not been translated into operative goals. In EU chemicals policy, the precautionary principle is certainly not the predominant aspect' (Boye 2000). Yet, one representative of a major NGO saw some changes and, asked whether the precautionary principle had influenced regulators at all, said that 'they are slowly learning' (personal interview 2001).

A few factors seem to be behind the slow transfer of precautionary thinking from rhetoric to practice within Community chemicals management. First of all, the burden of proof is still largely on regulators to prove that a chemical is not safe, rather than the producer and/or seller having to show data that it will not have adverse environmental and human health effects. This continues to put a heavy burden on Community assessors and policy-makers and makes it difficult to move away from the traditional risk-based management system towards a management system based on precaution. Partially related to this problem, there has been a tendency to spend a significant amount of time collecting data for long and detailed risk assessment documents which are scientifically detailed but not always regarded as useful by policy-makers for policy-making purposes (personal interviews 2001). As such, there seem to be gains to be made by making assessment processes more closely linked to perceived policy needs.

One interesting finding in this study is that the OECD acted as an early forum for responding to 'early warnings' in both cases. The OECD action on PCBs in 1973 was the first concerted action by more than twenty countries to control an environmental chemical (Lönngren 1992: 197). The OECD was also the first international forum to take action on BFRs, in 1995, when it negotiated a voluntary agreement with industry to limit production. Precautionary ideas were also referred to in the OECD relatively early. Several studies have looked at chemicals management (Brickman et al. 1985; Krueger and Selin 2002; Selin and Eckley 2003), but the role of the OECD in this area has not been subject to much attention (mainly, e.g. Lönngren 1992). Future research could look in more detail at the OECD and its influence on country and Community chemicals regulation.

\section{TOWARDS MORE PRECAUTION?}

Precaution has been a part of Community discourse for fifteen years and treaties for ten years; yet despite substantive changes in debate and international pronouncements, this study indicates that the precautionary principle has had little effect on actual policy-making as a means to address type 1 errors, making it a case of all talk and little action. Without clear changes in regulatory practice, mere establishment of the precautionary principle as a general guideline for policy-making has had little effect on regulation. As such, the 
observation by O'Riordan and Cameron in 1994 that precaution has had little impact on specific Community environmental policy-making seems still to be true a decade later. This is despite the fact that these cases fall into an issuearea that has been identified as generally suitable for precautionary action.

The results of this study suggest some important implications for understanding the influence of environmental leader states in Community policymaking. The leader states have been influential in pushing chemicals issues on to the Community agenda and shaping precautionary debate and language in Community treaties and texts, but in the two cases of PCBs and BFRs, regulatory action was not substantially more precautionary in later years. In other words, environmental leader states managed to influence Community debate much more than policy-making. To this end, environmental leaders and advocates for more precautionary regulation need to ask why the regulatory system has been so slow to change, and if there could be more successful strategies to encourage implementation of the precautionary regulation to reduce type 1 errors than have been engaged in to date. As discussed above, there seem to be several reasons why there has been little change in regulatory practice, including few changes in the burden of proof and partial disconnection between assessment and policy-making.

Issues relating to the future of Community activities on hazardous chemicals are timely. The Community regulatory system for managing existing and new hazardous chemicals is currently subject to major revisions (European Commission 2001b). These revisions include efforts by the member states, the Commission, the chemical industry, and environmental advocacy groups to design a more effective Community chemicals management system. Such efforts include the development of the Registration, Evaluation and Authorization of Chemicals (REACH) programme. Past Community assessments of chemicals have been slow, and many chemicals in use lack relevant assessment data. At the same time, many new chemicals are introduced on a regular basis, making it impossible to conduct extensive multi-year assessments for every single chemical. The goal with the new chemicals strategy is to develop relatively simple, yet reliable, means to assess large numbers of chemicals in a timely manner that will provide a basis for effective environmental and human health protection.

Environmental leader states are playing a significant role in the reshaping of the Community chemicals management system, and are, among other things, actively pushing for more precaution in future Community chemicals regulation (Swedish Government 2002). This involves trying to find ways in which precautionary thinking can be more effectively operationalized in actual regulation by better linking assessment and policy-making. Efforts also focus on establishing clearer requirements such that, in order to market chemicals, producers will have to provide data on toxicity, essentially reversing the burden of proof. If fully implemented for both existing and new chemicals, this could mean a large step forward for precautionary thinking and policy making in the EU and would address important shortcomings of the current system. 
Addresses for correspondence: Noelle Eckley, Harvard University, Department of Earth and Planetary Sciences, 29 Oxford Street, Cambridge, MA 02138, USA. email: eckley@fas.harvard.edu/Henrik Selin, Linköping University and Massachusetts Institute of Technology, Department of Urban Studies and Planning, 77 Massachusetts Avenue, Room 9-316, Cambridge, MA 02139, USA. email: hselin@mit.edu

\section{ACKNOWLEDGEMENTS}

This research was supported by a Fulbright grant, a Harvard University Radcliffe Traveling Fellowship, and the Knut and Alice Wallenberg Foundation. The authors wish to thank the European Environment Agency, especially David Stanners and David Gee, people involved in European chemicals management who were interviewed as part of the study, William C. Clark, and two anonymous reviewers for helpful comments on earlier drafts.

\section{NOTES}

1 This is not the only way to deal with type 1 errors and different societies have chosen different methods to try to address these risks. In the US, for example, such risks have historically been addressed through judicial proceedings.

2 Eight formal interviews and numerous more informal conversations were conducted as part of this research. Interviews were conducted with regulators, policy-makers, and NGO representatives in Brussels (March 2001), Johannesburg (during the 5th Intergovernmental Negotiating Committee session for the Stockholm Convention on POPs, December 2000), and Copenhagen (between September 2000 and June 2001).

3 In addition, the US, particularly through the EU Committee of the American Chamber of Commerce, has been a stern critic of the precautionary principle's application in the European context (personal interview 2001).

4 Some early multilateral environmental agreements such as the 1972 Convention for the Prevention of Marine Pollution by Dumping from Ships and Aircraft (Oslo Convention) and the 1974 Convention for the Prevention of Marine Pollution from Land-based Sources (Paris Convention) required parties to eliminate marine dumping and pollution from land-based sources of hazardous organohalogen substances, but did not specifically mention PCBs.

5 Parties to the 1974 Helsinki Convention were Denmark, the Federal Republic of Germany, Finland, the German Democratic Republic, Poland, the Soviet Union and Sweden.

6 Current HELCOM contracting parties are: Denmark, Estonia, Finland, Germany, Latvia, Lithuania, Poland, the Russian Federation, Sweden, and the European Community. OSPAR contracting parties are: Belgium, Denmark, Finland, France, Germany, Iceland, Ireland, Luxembourg, the Netherlands, Norway, Portugal, Spain, Sweden, Switzerland, the United Kingdom, and the European Community.

7 All EU countries signed both the CLRTAP POPs protocol and the Stockholm POPs convention. For updated information on ratification status of the CLRTAP protocol, see http://www.unece.org/env/lrtap/status/98pop—st.htm. For updated 
information on ratification status of the Stockholm convention, see http://www.chem.unep.ch/sc/documents/signature/signstatus.htm.

8 Polybrominated diphenyl ethers (PBDEs) are also known as polybrominated diphenyl oxides (PBDPOs); for consistency, they will be referred to as PBDEs here, though several of the assessments of these substances use the latter name.

\section{REFERENCES}

Andersen, M.S. and Liefferink, D. (eds) (1997) European Environmental Policy: The Pioneers, Manchester: Manchester University Press.

Andersson, O. and Blomkvist, G. (1981) 'Polybrominated aromatic pollutants found in fish in Sweden', Chemosphere 10(9): 1051-60.

Anonymous (1966) 'Report of a new chemical hazard', New Scientist 32(525): 612.

Bäckstrand, K. (2001) What Can Nature Withstand? Science, Politics and Discourses in Transboundary Air Pollution Diplomacy, Lund: Lund Political Stud, 116.

Bekesi, J.G., Holland, J.F., Anderson, H.A., Fischbein, A.S., Rom, W., Wolff, M.S. and Selikoff, I.J. (1978) 'Lymphocyte function of Michigan dairy farmers exposed to polybrominated biphenyls', Science 199: 1207-9.

Boehmer-Christiansen, S. (1994) 'The precautionary principle in Germany - enabling government', in T. O'Riordan and J. Cameron (eds), Interpreting the Precautionary Principle, London: Earthscan, pp. 31-60.

Boye, M. (2000) 'Chemicals in our daily life: why EU chemicals legislation is relevant for you', Copenhagen: The Danish Ecological Council.

Brickman, R., Jasanoff, S. and Ilgen, T. (1985) Controlling Chemicals: The Politics of Regulation in Europe and the United States, Ithaca: Cornell University Press.

Cameron, J. (2001) 'The precautionary principle in international law', in T. O'Riordan, J. Cameron and A. Jordan (eds), Reinterpreting the Precautionary Principle, London: Cameron May, pp. 113-42.

Canadian Council of Resource and Environment Ministers (1986) 'The PCB story', Toronto, August.

Carson, R. (1962) Silent Spring, Cambridge: The Riverside Press.

Clark, W.C., Mitchell, R.B., Cash, D.W. and Alcock, F. (2002) 'Information as influence: how institutions mediate the impact of scientific assessments on global environmental affairs', Cambridge, MA: Kennedy School of Government, Harvard University, Faculty Research Working Paper RWP02-044.

Colborn, T., Dumanoski, D. and Myers, J.P. (1996) Our Stolen Future, New York: Dutton.

Danish Environmental Protection Agency (2000) 'Action plan for brominated flame retardants', Copenhagen, March.

de Boer, J., Wester, P.G., Klamer, H.J.C., Lewis, W.E. and Boon, J.P. (1998) 'Do flame retardants threaten ocean life?, Nature 394: 28-9.

Earth Negotiations Bulletin (2000) 'POPs-5 \#5 Highlights', ENB, 8 December 2000.

Eckley, N. (2002) 'Dependable dynamism: lessons for designing scientific assessment processes in consensus negotiations', Global Environmental Change 12: 15-23.

ENDS (1998a) 'Fire retardants light up pollution conference', ENDS Daily, 17 August 1998.

ENDS (1998b) 'Global action urged on bromine chemicals', ENDS Daily, 10 September 1998.

ENDS (1999) 'Sweden to ban brominated flame retardants', ENDS Daily, 15 March 1999.

ENDS (2001) 'PentaBDE targeted for EU phase-out', ENDS Daily, 23 January 2001.

ENS (2001) 'EU lawmakers vote broad fire retardant ban', Environment News Service, 6 September 2001. 
European Commission (2000a) 'Comments from the European Commission Services to the Codex Secretariat', 11 October 2000. Codex Committee on General Principles.

European Commission (2000b) 'Communication from the Commission on the Precautionary Principle', Brussels, 2 February 2000. Commission of the European Communities. COM(2000)1.

European Commission (2001a) 'European Governance: A White Paper', Brussels, 25 July 2001. European Commission. (COM 2001) 428.

European Commission (2001b) 'White Paper: Strategy for a Future Chemicals Policy', Brussels, 27 February 2001. European Commission. COM(2001)88 final.

Freestone, D. and Hey, E. (eds) (1996) The Precautionary Principle and International Law: The Challenge of Implementation, International Environmental Law and Policy Series, The Hague: Kluwer Law International.

Haigh, N. (1994) 'The introduction of the precautionary principle into the UK', in T. O'Riordan and J. Cameron (eds), Interpreting the Precautionary Principle, London: Earthscan.

Hardy, M.L. (1997) 'Regulatory Status and Environmental Properties of Brominated Flame Retardants Undergoing Risk Assessment in the EU: DBDPO, OBDPO, PeBDPO and HBCD'. 6th European Meeting on Fire Retardancy of Polymeric Materials, Lille, France.

Harremöes, P., Gee, D., MacGarvin, M., Stirling, A., Keys, J., Wynne, B. and Vaz, S.G. (eds) (2002) The Precautionary Principle in the 20th Century, London: Earthscan.

Helsinki Commission (2001a) 'Polychlorinated biphenyls (PCBs): a compilation and evaluation of the information given by the contracting parties with the focus on legislative situation, current uses, stockpiles and releases', Helsinki, Finland, July 2001. Baltic Marine Environment Protection Commission.

Helsinki Commission (2001b) 'Polychlorinated biphenyls (PCBs): a compilation of information, derived from HELCOM recommendations, EU Directives, UN-ECELRTAP, UNEP and OSPAR, and analysis of appropriate measures aiming at safe handling and reduction of releases of PCB from PCB-containing equipment in use', Helsinki, Finland. Baltic Marine Environment Protection Commission.

Hutzinger, O., Frei, R.W., Merian, E. and Pocchiari, F. (eds) (1982) Chlorinated Dioxins and Related Compounds: Impact on the Environment. Proceedings of a Workshop held at the Istituto Superiore di Sanita, Rome, Italy, 22-24 October 1980, Pergamon Series on Environmental Science, Oxford: Pergamon Press.

Ikonomou, M.G., Rayne, S. and Addison, R.F. (2002) 'Exponential increases of the brominated flame retardants, polybrominated diphenyl ethers, in the Canadian Arctic from 1981 to 2000', Environmental Science and Technology 36(9): 1886-92.

International Programme on Chemical Safety (IPCS) (1994a) 'Brominated diphenyl ethers', Environmental Health Criteria 162, Geneva: World Health Organization.

International Programme on Chemical Safety (IPCS) (1994b) 'Polybrominated biphenyls', Environmental Health Criteria 152, Geneva: World Health Organization.

Jacobson, J.L. and Jacobson, S.W. (1996) 'Intellectual impairment in children exposed to polychlorinated biphenyls in utero', New England Journal of Medicine 335: 783.

Jansson, B. and Asplund, L. (1987) 'Brominated flame retardants: ubiquitous environmental pollutants', Chemosphere 16(10-12): 2343-9.

Jasanoff, S. (1990) The Fifth Branch: Science Advisers as Policymakers, Cambridge, MA: Harvard University Press.

Jasanoff, S. and Wynne, B. (1998) 'Science and decisionmaking', in S. Rayner and

E.L. Malone (eds), Human Choice and Climate Change, Vol. 1: The Societal Framework, Columbus: Battelle Press. 
Jensen, S., Johnels, A.G., Olsson, M. and Otterlind, G. (1969) 'DDT and PCB in marine animals from Swedish water', Nature 224: 247.

Jordan, A. (2001) 'The precautionary principle in the European Union', in T. O'Riordan, J. Cameron and A. Jordan (eds), Reinterpreting the Precautionary Principle, London: Cameron May, pp. 143-61.

Koppe, J.G. and Keys, J. (2002) 'PCBs and the precautionary principle', in P. Harremoës, D. Gee, M. MacGarvin, A. Stirling, J. Keys, B. Wynne and S.G. Vaz (eds), The Precautionary Principle in the 20th Century, London: Earthscan, pp. 64-78.

Krimsky, S. (2000) Hormonal Chaos: The Scientific and Social Origins of the Environmental Endocrine Hypothesis, Baltimore: Johns Hopkins.

Kronsell, A. (1997) 'Sweden: setting a good example', in M.S. Andersen and D. Liefferink (eds), European Environmental Policy: The Pioneers, Manchester: Manchester University Press.

Krueger, J. and Selin, H. (2002) 'Governance for sound chemicals management: the need for a more comprehensive global strategy', Global Governance 8: 323-42.

Larsson, P. and Okla, L. (1989) 'Atmospheric transport of chlorinated hydrocarbons to Sweden in 1985 compared to 1973', Atmospheric Environment 23(8): 1699-711.

Liefferink, D. and Andersen, M.S. (1998) 'Strategies of the "green" member states in EU environmental policy-making', Journal of European Public Policy 5(2): 254-70.

Liftin, K. (1994) Ozone Discourses: Science and Politics in International Environmental Cooperation, New York: Columbia University Press.

Lönngren, R. (1992) International Approaches to Chemicals Control: A Historical Overview, Stockholm: KEMI.

McCormick, J. (2001) Environmental Policy in the European Union, New York: Palgrave.

Moilanen, R., Pyysalo, H., Wickström, K. and Linko, R. (1982) 'Time trends of chlordane, DDT, and PCB concentrations in pike [esox-lucius] and Baltic herring [clupea-harengus] in the Turku archipelago, northern Baltic Sea for the period 1971-1982', Bulletin of Environmental Contamination and Toxicology 29(3): 334-40.

Nichols, J.K. and Crawford, P.J. (1983) Managing Chemicals in the 1980s, Paris: OECD.

Olsson, M. and Reutergårdh, L. (1986) 'DDT and PCB pollution trends in the Swedish aquatic environment', Ambio 15(2): 103-9.

Organization for Economic Co-operation and Development (OECD) (1973a) 'Decision of the Council on protection of the environment by control of polychlorinated biphenyls', 13 February 1973, Paris: OECD.

Organization for Economic Co-operation and Development (OECD) (1973b) 'Polychlorinated biphenyls: their use and control', Paris: OECD Environment Directorate.

Organization for Economic Co-operation and Development (OECD) (1981) 'OECD and chemicals control', Paris, December. The High Level Meeting of the Chemicals Group of the Environment Committee.

Organization for Economic Co-operation and Development (OECD) (1987) 'Decision-Recommendation of the Council on further measures for the protection of the environment by control of polychlorinated biphenyls', 13 February 1987, Paris: OECD.

Organization for Economic Co-operation and Development (1994) 'Risk Reduction Monograph No. 3: Selected brominated flame retardants: background and national experience with reducing risk', Paris: OECD Environment Directorate.

O'Riordan, T. and Cameron, J. (eds) (1994) Interpreting the Precautionary Principle, London: Earthscan. 
O'Riordan, T., Cameron, J. and Jordan, A. (2001) Reinterpreting the Precautionary Principle, London: Cameron May.

OSPAR Commission for the Protection of the Marine Environment of the NorthEast Atlantic (1998a) 'OSPAR strategy with regard to hazardous substances', Sintra, Portugal, 22-23 July 1998 OSPAR: 1998-16.

OSPAR Commission for the Protection of the Marine Environment of the NorthEast Atlantic (1998b) 'Sintra statement', Sintra, Portugal, 23 July 1998. OSPAR.

Raffensperger, C. and Tickner, J. (eds) (1999) Protecting Public Health and the Environment: Implementing the Precautionary Principle, Washington, DC: Island Press.

Ritter, L., Solomon, K.R., Forget, J., Sterneroff, M. and O’Leary, C. (1995) 'An assessment report on: DDT-aldrin-dieldrin-endrin-chlordane-heptachlorhexachlorobenzene-mirex-toxaphene-polychlorinated biphenyls-dioxins and furans', December. International Programme on Chemical Safety (IPCS) within the framework of the Inter-Organization Programme for the Sound Management of Chemicals (IOMC).

Saladin, C. (2000) 'Precautionary principle in international law', International Journal of Occupational and Environmental Health 6(4): 270-80.

Sandberg, E. (2001) The Precautionary Principle in Swedish Chemicals Policy: The Role of Precaution in Chemicals Policy, Vienna: Diplomatic Academy.

Sandin, P. (1999) 'Dimensions of the precautionary principle', Human and Ecological Risk Assessment 8(3): 889-907.

Sandin, P. and Hansson, S.O. (2002) 'The default value approach to the precautionary principle', Human and Ecological Risk Assessment 8(3): 463-71.

Sandin, P., Peterson, M., Hansson, S.O., Rudén, C. and Juthe, A. (2002) 'Five charges against the precautionary principle', Journal of Risk Research 5(4): 287-99.

Selin, H. (2003) 'Regional POPs policy: the UNECE-CLRTAP POPs agreement', in D.L. Downie and T. Fenge (eds), Northern Lights Against POPs: Combating Toxic Threats in the Arctic, Montreal: McGill-Queens University Press.

Selin, H. and Eckley, N. (2003) 'Science, politics and persistent organic pollutants: the role of scientific assessments in international environmental co-operation', International Environmental Agreements: Politics, Law, and Economics 3: 17-42.

Selin, H. and VanDeveer, S.D. (2004) 'Baltic Sea Hazardous Substances Management: Results and Challenges', Ambio.

Skjærseth, J.B. (2000) North Sea Cooperation: Linking International and Domestic Pollution Control, Manchester: Manchester University Press.

Stirling, A. (1999) 'On science and precaution in the management of technological risk', May. Final Report of a Project for the EC Forward Studies Unit under the auspices of the ESTO Network.

Stirling, A. and Mayer, S. (2000) 'Precautionary approaches to the appraisal of risk: a case study of a genetically modified crop', International Journal of Occupational and Environmental Health 6(4): 296-311.

Swedish Committee on New Guidelines on Chemicals Policy (2000) 'Summary of the report of the Swedish Committee on New Guidelines on Chemicals Policy, "Nonhazardous products - proposals for implementation of new guidelines on chemicals policy", Stockholm, 5 June 2000.

Swedish Government (2002) 'Swedish views on the authorisation system and comments on accelerated risk management', Stockholm, 21 November 2002. Government of Sweden.

Swedish National Chemicals Inspectorate (KEMI) (1999) 'Phase-out of PBDEs and PBBs: report on a governmental commission', Solna, Sweden, 15 March 1999, KEMI.

Swedish National Chemicals Inspectorate (KEMI) (2000) 'Flamskyddsmedel - ett brännande problem', Solna, Sweden, December 2000, Kemikalieinspektionen. 
Tegethoff, B.M. (2000) Chemical Awareness - Future Demands for the European Chemicals Policy, Copenhagen: Chemicals under the Spotlight.

Tickner, J.A. (1999) 'A map toward precautionary decision making', in C. Raffensperger and J. Tickner (eds), Protecting Public Health and the Environment: Implementing the Precautionary Principle, Washington, DC: Island Press.

United Nations Conference on Environment and Development (1992) Rio Declaration on Environment and Development, Rio de Janeiro.

United Nations Economic Commission for Europe (UNECE) (1998) 'Protocol to the 1979 Convention on Long-Range Transboundary Air Pollution on Persistent Organic Pollutants', Aarhus, Denmark.

United Nations Environment Programme (UNEP) (1995) 'Decision 18/32: Persistent Organic Pollutants, 25 May 1995. UNEP Governing Council.

United Nations Environment Programme (2001) 'Final Act of the Conference of Plenipotentiaries on the Stockholm Convention on Persistent Organic Pollutants', Stockholm, 5 June 2001. Conference of Plenipotentiaries on the Stockholm Convention on Persistent Organic Pollutants, 22-23 May 2001. UNEP/POPS/ CONF/4.

Weinberg, A.M. (1972) 'Science and trans-science', Minerva 10: 209-22.

World Wide Fund for Nature (WWF) (2000) 'WWF briefing: brominated flame retardants', Bremen, Germany. 